\title{
Limitations of urban development in land of social origin: the case of the metropolitan area of the city of Toluca (ZMCT)
}

\begin{abstract}
The paper analyses the occupation process of agricultural land with social origin and urban uses in the metropolitan area of the city of Toluca (ZMCT), and the barriers that the population and authorities have to face in order to regularize the settlements. A mixed research method was applied, which included the use of quantitative and qualitative methods, on the basis of a theoretical analysis, to build a methodological research model, which was applied to an empirical case in municipal and metropolitan areas. The analysis of the 14 municipalities that constitute ZMCT shows that the barriers for regularizing settlements in land of social origin are the result of legal/ administrative inefficiencies due to the incapability of local city halls to address the collective needs of society.
\end{abstract}

Keywords

Space $\bullet$ land $\bullet$ urban development $\bullet$ Toluca

(C) University of Warsaw - Faculty of Geography and Regional Studies

\author{
Pedro Leobardo Jiménez-Sánchez ${ }^{1}$ \\ Juan Roberto Calderón-Maya² \\ Héctor Campos-Alanís ${ }^{3}$ \\ 'Professor School of Urban and Regional Planning, \\ University of the State of Mexico, Mexico \\ e-mail:pl_js@hotmail.com; \\ ${ }^{2}$ Vice Principal School of Urban and Regional \\ Planning, University of the State of Mexico, Mexico \\ e-mail: jrcalderonm@uaemex.mx \\ ${ }^{3}$ Director School of Urban and Regional Planning, \\ University of the State of Mexico, Mexico \\ e-mail: hect_51@hotmail.com \\ Received: 21 January 2015 \\ Accepted: 22 January 2016
}

Introduction

In recent decades, territorial topics have determined a variety of physical and spatial forms that correspond to social relationships. Land configuration shows the growth and expansion of cities as a framework that involves social relationships and their collective needs. Space occupation is the main topic of the studies on how cities grow and expand. The state organizes, regulates and controls space occupation as well as city growth, through the use of legal and administrative norms, which establish territory obligations in order to satisfy the community's needs.

State and society interact and contribute to the creation of a heterogeneous social space. Authorities' functions have been overwhelmed by the actions of society, satisfying their land and dwelling needs with their own resources and in unsuitable spaces for urban development.

The objective of this paper is to present partial results of the research project: Municipal control mechanisms of space occupation in the suburbs of the metropolitan area of the city of Toluca (ZMCT), 1983-2010 (register number: UAEM-3109/2011, financed by the Autonomous University of the State of México), with the purpose of addressing this phenomenon from a territorial view, in order to establish the government's participation, and to identify the legal instruments and administrative systems implemented by Mexican city halls, as well as the causes of their failure.

The hypothetical approach is based on the arguments of Abott (2001), who stated that the main cause of incompetence is the lack of efficiency of systems and procedures in order to satisfy demands and collective needs, where public workers are part of a bureaucracy that is not in the position to face the problem, reflecting the authorities' incapacity to control illegal space occupancy.

The methodology is a reference for researchers, authorities and society, enabling the identification and understanding of the phenomenon and the causes of the administrative incompetence for attending collective needs. It will help knowledge development in legal and territorial areas, with a focus on the case of a low income population, who lack the possibility to participate in official land and dwelling programs, because of the lack of economic resources.

The aim of the research is to analyse the transformation of the occupancy process of land with social origin for an urban goal, with the purpose of identifying the legal and administrative limitations that should be controlled, regulated and organised by city halls in the ZMCT settlements.

The results fall into four different analyses:

1. Theoretical bases for conceptual variables of the methodological analysis model.

2. Legal bases for giving autonomy to the city halls in the arrangement of territory.

3. The incorporation process of social origin land to urban development.

4. Use of empirical data collection instruments. 


\section{Methodology}

This research used a deductive method with a systemic vision, a theoretical base of the study object, a conceptual variable description and the construction of a theory-methodological model applied to an empirical case.

Human geography and social science approaches were used as theoretical bases, through the French School of Urban Sociology and the proposals of Lefebvre (1991), Santos (1996, 2000) and Castells $(1977,1978)$, who explain the occupancy process of space from a social and geographic point of view. Likewise, the contributions of the Urban Sociology School of Chicago are based on Burgess (1967) and McKenzie (1967) (Lezama 2002), who analysed the phenomenon of the growth and enlargement of cities from a metropolitan point of view.

The empirical research used a mixed method (quantitative and qualitative), paying attention to the meaning of social relationships (Vela 2004). Quantitative methods have been used as a tool in order to explain social problems (Tarrés 2004); so, the data was obtained from people's experiences (Ander-Egg 1995). The process involved the development of a theoretical analysis in order to build an applied methodology for empirical cases.

Empirical results were obtained from a social and geographic study, the source being contact with people and social actors involve in the phenomenon. Gutiérrez (Sánchez 2004), made observations in the area, which allowed reflections to be made on various situations deriving from the social relationships that developed inside the space.

The quantitative data was obtained from non-structured interviews with civil servants from 14 city halls in ZMCT, who are in charge of the illegal space occupancy regulation process and the operative process of control and security mechanisms (Kahn \& Cannell 1977; Brimo 1972). The data was codified before being analysed and recorded. The result was the identification of social origin land occupancy limitations. The conclusions will help civil servants to make decisions and to control the territory.

\section{Theoretical Bases}

The analysis took into consideration the approaches of the French School of Urban Sociology, which is inspired by space transformations, including demographic changes, land expropriation for public infrastructure and land price increases within cities, achieving a new territory morphology under the capitalist model governing the State, as well as introducing public policies and the use of planning as the way to lead the growth of cities.

Following the line of the French School, the city is considered a place in which different forms of social alienation are involved (Lefebvre 1973; Castell 1977); on the other hand, territory is a place where it is possible to see physical elements of nature and socialization forms, in which agents and actors coexist and create social relationships.

On the subject of territory configuration, Santos (2000) explains: it is determined by a group of natural systems of a country or area and by the people's actions; also he defines space as an indissoluble group of object and action systems which is part of, and has a relationship with, nature. Within a territory, physical, natural and artificial elements are built up and consolidated in order to give it life and functionality with the intention of being a place where social relationships exist. Lefebvre (1991) considered that the space appears as a productive force for replacing nature with technical progress, knowledge; social organization forms and productive capabilities are reinforced; as a result, the space is transformed into a place where physical elements have social relationships to human beings. Furthermore, Castells (1978) said that it is very important to include an economical variable - for example, the way in which a "worker" contributes to transforming nature in order to get necessary goods for their social existence. According to Rueda (1999) and Del Soto (1987), it is possible to identify two mechanisms for space occupancy:

1. Legal

1. The occupancy of the space is regulated by the State. This is defined as a system that helps the dominant social class. State and society interact and contribute to the creation of a heterogeneous social space, in which a social group's behaviour frames space occupancy in order to satisfy their needs, through their own means and resources from an informal process of space occupation, where plans, legal and administrative procedures are not considered.

2. Illegal

This process corresponds to the structure of areas without any planning, qualification or programme. Rueda (1999) defines it as a spontaneous growth characterized by mobility and non-defined limits, as well as a lack of order and sociospatial perimeters along with the central areas. It is possible to identify two types:

a) Invasion: illegal occupation of agricultural, forestry, public or private lands. The invasion maybe gradual or by force. The former occurs on current human settlements, where the owner has a special relationship with the settlers. In the latter there is no link between the owner and the settlers, and the use of force is necessary.

b) Illegal sale: the sale of agricultural lands by associations or cooperatives with the aim of obtaining money. The sale is made by the holder of the common lands.

The Urban Sociological School of Chicago establishes some arguments for the analysis: Burgess (1967) and McKenzie (1967) (in Lezama 2002) analysed the social effects of urbanization from a biological point of view. According to Burgess (1967), a city grows in a concentric form, from the centre to the perimeter, where industry is located. It causes different social class settlements to appear: from the humblest to the richest. Burgess (1967) published his concentric zones theory, in which the expansion of a city is explained in various stages; the model includes five concentric circles that represent the expansion of a territory.

McKenzie (1967) (in Lezama 2002), contributed to the social and territorial perspective on the growth of cities; he also established a differentiated socio-spatial process in which urban is considered as a social phenomenon and the city as a physical structure, where all the processes take place. He established the "metropolitan model" theory, which examines the conurbation process of the urban nucleus, using the ecological approach and focusing on the social organization of urban space.

\section{Results}

Municipal autonomy for territorial order

The analysis identified some actions in the legal area which had strengthened the municipal autonomy in order to regulate its urban development; even though they have duties and faculties, it is observed that collective needs overflow the policies and legal instruments established, and as a result, there is an incapacity in terms of organisation, control and supervision. The Mexican Constitution (GR 2002) established rights and guarantees for Mexicans, as well as the legal bases for territorial order and land occupancy regulation. It also specified the city hall faculties for regulating urban development. In 1976 a legal framework was created in order to re-orientate the urban development and contribute to the modernization and social development processes.

In 1992, the latest general law proposal of the urban settlement was approved and printed in the Official Newspaper of the Federation in 1993 (GR 1993), reinforcing the municipal authority for urban matters and giving them the following responsibilities: 
administration, regulation and urban ordering. This determines the state faculty to establish: the necessary policy for ordering human settlements and for establishing the appropriate usage, reservation and destiny of land, water and forest, with the aim of performing, planning and regulating conservations, and improving and developing communal centres (GR 1993).

In 1999, sections $\mathrm{V}$ and $\mathrm{VI}$ of article 115 were modified to say: "Los municipios, en los términos de las leyes federales y estatales relativas, estarán facultados para formular, aprobar y administrar la zonificación y planes de desarrollo urbano municipal; participaren la creación y administración de sus reservas territoriales; controlar y vigilar la utilización del suelo en sus jurisdicciones territoriales; intervenir en la regulación de la tenencia de la tierra urbana; otorgar licencias y permisos para construcciones y participaren la creación y administración de sus reservas ecológicas".

Section VI says: "para el caso de que uno o más centros urbanos situados en territorio municipal de dos o más entidades federativas, formen o tiendan a formar una continuidad demográfica, la federación, las entidades federativas y los municipios respectivos, el ámbito de sus competencias, planearán y regularán de manera coordinada el desarrollo de dichos centros con apego a la ley federal de la materia..."

Under this legal precept, municipal authorities have the obligation to regulate the organisation and control of the human settlements in conjunction with other authorities.

\section{Control and supervision instruments}

The main problem in Mexico is that cities are growing without any regulation and this means that illegal settlements appear. Villar (2005) suggests that control and supervision instruments have been set by city halls in order to regulate and organise the growth of human settlements. These instruments have been identified as prescriptions that restrict and penalise, when appropriate, the public administration.

These instruments allow the authorities to control and regulate the land usage of the population, by means of the urbanity prescriptions published within the legal framework, in the form of licences and authorizations. In the state of Mexico it is possible to identify five instruments of control and supervision that are used:

a) Cédula informativa de zonificación (informative format for zone division): informs and orientates about the law; it is included in the municipal plans of urban development. It is applied with the purpose of identifying land usages, population densities, maximum intensities and possible restrictions for a specific piece of land.

b) Licencia de uso de suelo (land usage licence): determines the application of land with an urban purpose, meaning: land usage, population densities, maximum intensities of application and occupancy and possible restrictions.

c) Alineamiento y número oficial (line-up and official number): determines the limit-line of the land, which specifies the construction in relation to the street, according to that established in the municipal plan. An official number is assigned for each property.

d) Licencia de construcción (construction licence): authorizes the plans with technical and architectural characteristics according to the data contained in letters.

e) Aviso de terminación de obra (ending construction notification): states that the construction has been completed and that it fulfils all the administrative and legal procedures.

\section{ZMCT delimitation}

SEDESOL-CONAPO-INEGI recognizes a metropolitan zone as a cluster of 2 or more city halls where it is possible

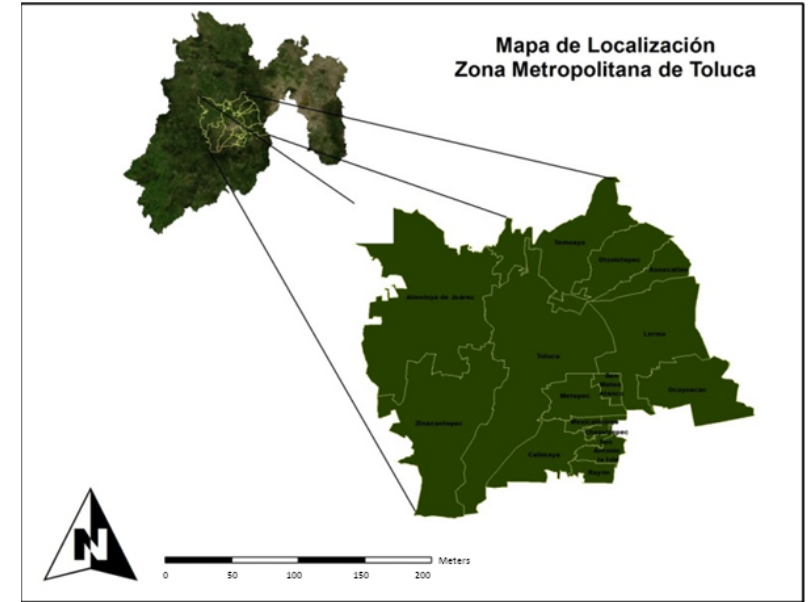

Figure 1. Localization and structure of the metropolitan area of the city of Toluca (ZMCT)

Source: Own elaboration based on INEGI data (INEGI 2010).

to localize a city with 50 thousand or more inhabitants. The urban area, functions and activities overflow the municipal limit, incorporating neighbouring city halls within a socioeconomic relationship (SEDESOL-CONAPO-INEGI 2005) . The main constituents for composing, defining and delimiting a metropolitan zone are: a city with a high population density, increasing socioeconomic and political supremacy, and a high concentration of economic activities and services.

ZMCT is the second most important of the 56 metropolitan zones in the country; it incorporates 14 city halls that constitute an urban agglomeration in the perimeter of Toluca city. It is the closest metropolitan zone to Valle de México, and its growth dynamic allows the deeper analysis of the theoreticalmethodological model in order to acquire empirical results.

ZMCT is divided into 14 municipalities (see Figure 1): Almoloya de Juárez, Calimaya, Chapultepec, Lerma, Metepec, Mexicaltzingo, Otzolotepec, Ocoyoacac, Rayón, San Antonio la Isla, San Mateo Atenco, Toluca, Xonacatlán and Zinacantepec (SEDESOL 2005).

Surveys were conducted with the employees of the 14 municipalities of ZMCT, who are in charge of the control and guarantee of land usage; the results are shown below.

\section{Irregularity indicators}

The human settlements have at least 10 similar characteristics, indicators that allow the measuring of the level of irregularity, which include: land possession, property document, risky and federal zone location, water, energy, drainage, sewage, and paving (see Figure 2).

The indicators of human settlements are:

1. Identifying the human settlements in the urban area of the city hall and $\mathrm{ZMCT}$, using the following categories:

Zone 1. Surface of municipal territory, which is consolidated as urban usage, with basic services, infrastructure and public services.

Zone 2. Surface of private property with irregular settlements through illegal procedures; there is a lack of basic services and infrastructure, which is why the municipal government does not invest there.

Zone 3. Surface with social land tenure (common land), with irregular settlements, set up in an illegal way; lack of basic services and infrastructure, and no investment. 


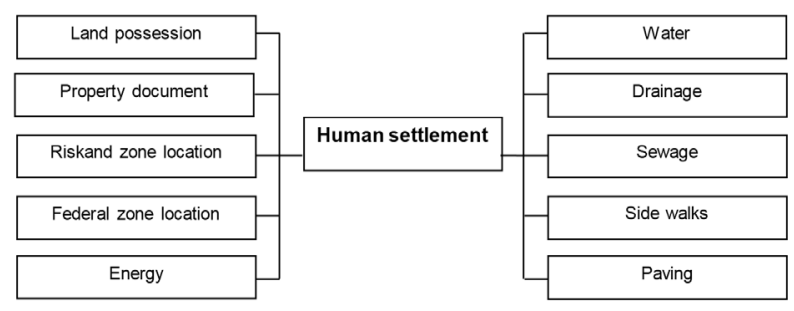

Figure 2. Irregularity indicator of human settlement Source: Own elaboration based on qualitative information from interviews.

Table 1. Area occupied by settlements in ZMCT

\begin{tabular}{|c|c|c|}
\hline Zone & Area(ha) & \% \\
\hline Zone 1 & 35.85 & 0.43 \\
\hline Zone 2 & $2,695.05$ & 31.96 \\
\hline Zone 3 & $5,575.28$ & 66.12 \\
\hline Zone 4 & 126.28 & 1.50 \\
\hline Total & $\mathbf{8 , 4 3 2 . 4 7}$ & $\mathbf{1 0 0 . 0 0}$ \\
\hline
\end{tabular}

Source: Own elaboration based on quantitative research work.

Zone 4. Set in risky zones, such as ravines, or areas with characteristics that do not contribute to urban usage. It is very difficult to regularize them because of their illegal character.

2. Location and quantification of the surface occupied by settlements in each of the identified zones (see Table 1).

Incorporation of social origin land into urban development The results allow the identification of the space occupancy processes in zones 1, 2, 3 and 4; these settlements occupy a total surface of $8,432.47$ ha, which means $2.82 \%$ of the total ZMCT surface.

Zone 1 represents $0.43 \%$ of the total; zone 2 is equivalent to $31.96 \%$; zone 3 is the biggest, with $66.12 \%$, and zone 4 occupies $1.50 \%$. In a general context, the proliferation of settlements can express the causes that explain why illegal or irregular land occupancy is the most useful, despite control and supervision instruments (see Graph 1).

1. Invasion $-13 \%$ of informers said that invasion is one of the most frequent causes of space occupancy. These actions are performed by people from the community on agricultural lands. The owner sells the land, even though he knows that legal occupancy is impossible.

2. Smallholding sale - this represents $16 \%$ of causes, and it refers to the sale of agricultural land; the owner determines the price, surface, streets, road access, and the number of payments. The lots do not fall under the city law.

3. Risky zone occupancy: this is the occupation of risky zones that may suffer natural disasters (flooding, landslides and ravines, among others). It is equivalent to $14 \%$ of causes.

4. Illegal buying - the illegal transaction of land, which does not have the basic characteristics necessary for urban development, and is therefore impossible to regulate; for example, ravines, bodies of water, land involved in litigations, protected ecological areas, etc. It represents $14 \%$ of causes.

5. Buying without advice- this also represents $14 \%$. During the deal, the location, price and payment period are adequate, but there is a lack of orientation in the process, so the space does not have the basic services and infrastructure.
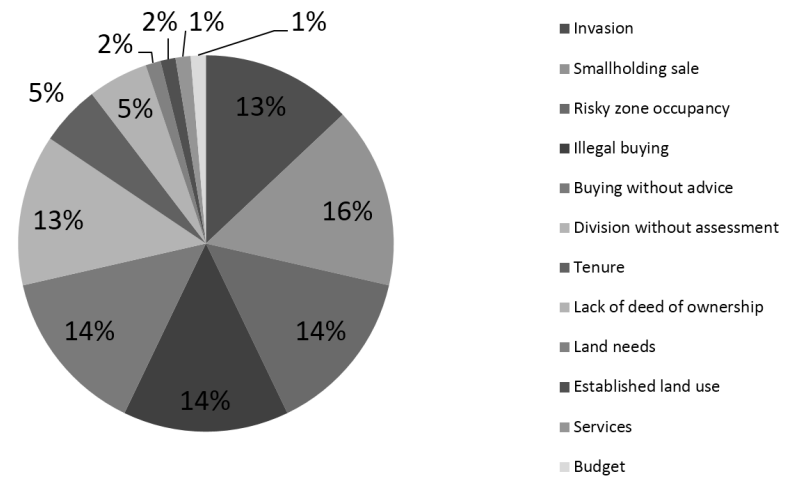

Graph 1. Reasons for existence of human settlements Source: Own elaboration based on interviews

6. Lots (without orientation) - the territory is divided into lots without any assessment of the city law. This usually happens with agricultural land, and it constitutes $13 \%$ of causes.

7. Tenure - the occupancy of social origin land, which the holder divides into lots without authorization. These lots are not considered by the city hall and their regularization is slow and inefficient. This represents $5 \%$.

8. Lack of deed of ownership - $5 \%$ of cases do not have the necessary documents for their lands, meaning that they cannot regulate their lots. In the case of a private property the ownership documents have a lack of notarized statement and the appropriate registration at Instituto de la Función Registral, which limits the possibility to get licences and authorizations.

9. Land needs - this refers to the need of a society to own a piece of land in order to build their house, no matter the location, tenure or natural characteristics of the lot. The price and payment period are the elements which define the acquisition. It represents $2 \%$ of causes.

10. Land usage - the acquisition of agricultural land corresponds to $2 \%$ of causes. The locations and usage of the land according to the city law are not relevant for this factor.

11. Services - in an illegal transaction of land, the lots lack basic services and infrastructure, as well as public services. This represents $1 \%$ of causes.

12. Budget - this also represents $1 \%$ of causes, and is occurs because of city halls' budgets for regulating settlements and the introduction of public services being limited.

In zone 4, the main characteristic is the social origin of the land, which is occupied illegally, so this zone faces the major problems of tenure regularization and the lowest investment in urban infrastructure. Occupancy of this zone has occurred as a result of the authorities' lack of control in the common land clusters. These clusters allow the occupation of the land without order, technical or legal urban assessment; neither are these lands controlled by published legal papers. Illegal occupation is tolerated by the authorities, because the community does not have the documents required by the city law.

\section{Socio-territorial limitations}

This section addresses the main problems that communities face in occupying land. These limitations prevent the occupation of the land in ZMCT in an organized and controlled manner. There are 9 main problems:

1. Communal interest. This represents $14 \%$ of limitations. Members of the community carry out illegal and informal 
actions and are not interested in adhering to the controls and supervisory instruments that limit the future regularization.

2. Holder interest. This represents $7 \%$ of all limitations, because holders do not want the authorities to get involved in their business, so the land division is carried out without any legal assessment or authorization.

3. Common holders. This represents $4 \%$; they argue that the land belongs to them and the occupancy is arranged according to their needs and do not take into consideration what the authorities say.

4. Tenure. Regularization of the land is the responsibility of the holder and common holders, not the authorities. This represents $18 \%$ of limitations.

5. Private property. There is a lack of notarized documents and the appropriate registration at Instituto de la Función Registral. This represents $18 \%$ of limitations.

6. Risky zone. Settlements are located on land not suitable for urban usage, and the authorities are not able to regulate or provide services to them. This limitation represents $21 \%$ of the total.

7. Illegal sale. This is related to the sale of social origin land without legal assessment, including usage, planning, legal and administrative instruments. It represents $7 \%$ of limitations.

8. Gradual invasion. The appropriation and occupation of agricultural land with the approval of the owner, but nor the authorities.

9. Land usage. Occupancy occurs on land that does not possess the appropriate urban characteristics; usage and population density are not considered. This limitation represents $4 \%$.

\section{Legal-administrative limitations}

The city hall government aims to have an impact on their land organization, including in the legal sense, through the use of control and supervision instruments; however, there are problems in the administrative process (see Graph 2), such as:

a) Physical space

$42.9 \%$ of the city halls have adequate physical space to develop their functions, providing quality and satisfactory services to users. In the remaining city halls, the provision of services is inefficient, because of the lack of space.

b) Specialized personnel.

$78.9 \%$ of city halls have specialized personnel (engineers, architects, planners, geographers, among others), helping to provide efficient services and speed up processes. On the other hand, in the remaining city halls, the personnel learnt the processes as a result of necessity and repetition.

c) Forms

$71 \%$ of city halls use forms that are diverse, complex and confused. The latter are easy, clear and allow processes to be speeded up.

d) Communal limitations in fulfilling requirements Just $57 \%$ of the community pays attention to the requirements, because of:

Tenure - this represents $31 \%$ of limitations and has two causes: a) the community does not follow the administrative procedure established by the holders and common holders in order to get land, and b) lots and subdivisions are irregular and do not take the city law into consideration.

Risky zones - buildings in these zones represent $16 \%$ of limitations because they do not have licences or authorizations from the city halls.
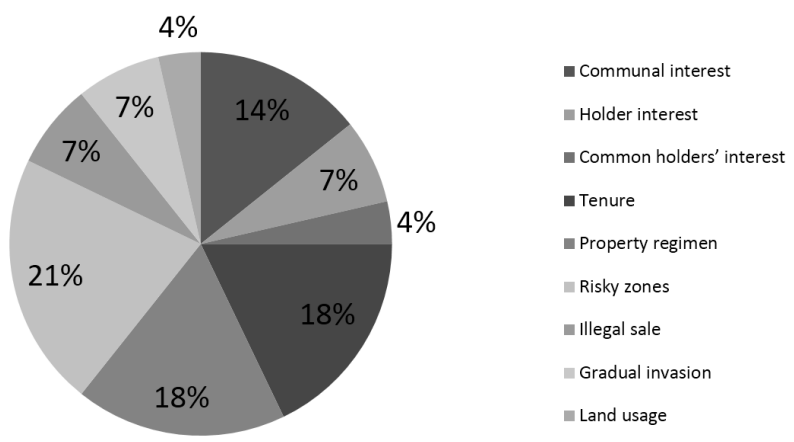

Graph 2. Limitations for regularizing human settlements Source: Own elaboration based on quantitative information.

Deed of ownership - $31 \%$ of the community does not fulfil the requirements, because they do not have a deed of ownership regulated by the appropriate authorities.

Individual beliefs- this represents $11 \%$; the community considers the land to be their own property, and they do not have any obligation to meet the legal and administrative requirements.

Traditions and habits - in Mexicaltzingo and Chapultepec, the use of land is related to social and personal needs, which means that the administrative and legal processes are not require by the authorities. This limitation represents $11 \%$ of the total.

\section{Conclusions}

The approach that motivated this analysis is as follows: interactions between the society and the government which contribute to the composition of a heterogeneous space, in which the behaviours of social groups determine the manners of space occupancy in order to satisfy their needs, even though there is a state incapacity to face collective problems. This situation reflects the inability of the authorities to control the illegal space occupation of social origin agricultural land.

Societal actions focus on the occupancy of illegal space because of the financial problems that limit their participation in official programs; as a consequence, the only option is acquiring land by illegal means.

The occupancy of social origin lands occurs in the area of all city halls, but more specifically in those that have less demographic and political importance, and this is a generalized phenomenon on a metropolitan level.

In the analysis, the State shows poor faculties for organizing, controlling and supervising its urban development. These faculties are over whelmed and limited by the actions of the society, who occupy the land without following any legal or administrative procedures.

The legal instruments that function in the city halls are not in accordance with social needs, because they limits their functions, and because they are not applied in the correct way for social lands.

City halls do not possess the faculties and conditions to control the illegal occupancy of agricultural land; they also face problems in authorizing and operating control processes and supervision instruments. 


\section{References}

Abott, J 2001, Remendar el tejido urbano, Mimeo.

Ander-Egg, E 1995, Autoconstrucción y ayuda mutua. El trabajo social en programas de viviendas, LUMEN, Argentina.

Brimo, A 1972, 'Les methods d'observation des individus' in Les méthodes des sciences sociales, pp. 206-221, Montchreistien, París.

Burgess, E 1967, 'The Growth of the City', in The City, eds R Park, E Burgess \& R MacKenzie, University of Chicago Press, Chicago, pp. 47-62.

Castell, M 1977, The Urban Question, Edward Arnold, London.

Castells, M 1978, City, Class and Power, Macmillan, Basingstoke

Del Soto, H 1987, El otro sendero, Diana, México

GR 2002, 'Constitución Política de los Estados Unidos Mexicanos' in Diario Oficial de la Federación, Gobierno de la República, México, pp. 22-27.

GR 1993, 'Ley General de Asentamientos Humanos', in Diario Oficial de la Federación, Gobierno de la República, México, pp. 8-10.

Gutiérrez, J \& Delgado, M 1995, 'Teorías de la observación', in Método y técnicas cualitativas de investigación en ciencias sociales, J Gutiérrez \& M Delgado, pp. 2-16, Síntesis, España.

Kahn, R \& Cannell, Ch 1977, 'Entrevista. Investigación Social', in Enciclopedia internacional de las ciencias sociales, ed David, S 1977, Aguilar, Madrid, pp. 266-276.

Lefebvre, H 1973, La revolución urbana, Alianza, Madrid.

Lefebvre, H 1991, The prodution of Space, Blackwell, London.

Lezama, J 2002, Teoría social, espacio y ciudad, El Colegio de México, México.
Mackenzie, R 1967, 'The Ecological Aproach to the Study of the Human Community', in The City, eds R Park, E Burgess \& R MacKenzie, pp. 63-79, University of Chicago Press, Chicago.

Rueda, R 1999, Mecanismos del crecimiento urbano en el Valle de Cuernavaca, PRAXIS, México.

Sánchez, R 2004, 'La observación participante como escenario y configuración de la diversidad de significados', in Observar, escuchar y comprender sobre la tradición cualitativa en la investigación social, ed M Tarrés, Porrúa, México, pp. 97-131.

Santos, M 2000, La naturaleza del espacio, Ariel, Barcelona, España.

Santos, M 1996, Metamorfosis del espacio habitado, Oikos-Tau, Barcelona, España.

SEDESOL-CONAPO-INEGI 2005, Delimitación de las zonas metropolitanas en México, SEDESOL-CONAPO-INEGI, México.

Tarrés, M 2004, 'Lo cualitativo como tradición. Paradigma positivo y la contribución de Durkheim', in Observar, escuchar y comprender sobre la tradición cualitativa en la investigación social, ed M Tarrés, Porrúa, México, pp. 35-60.

Vela, F 2004, 'Un acto metodológico básico de la investigación social: la entrevista cualitativa', in Observar, escuchar y comprender sobre la tradición cualitativa en la investigación social, ed M Tarrés, Porrúa, México, pp. 63-95.

Villar, A 2005, La impotencia municipal en el desarrollo urbano, UAEMex, México. 